robust species with interspace strongly transverse (Fig. 39a). Prosternal spine variable, rather short. Ovipositor similar to that of extremus or a little stouter.

M. fasciatus.

Io'. Hind femora not obliquely banded, rarely with traces of dusky on dorsal part of inner face. Hind tibiae variable. Tegmina brownish olive, immaculate or very nearly so. General color varying from greenish to brownish olive, with black markings. Interspace varying from sub-quadrate to rather strongly transverse. Tegmina variable in length, sometimes passing hind femora. Prosternal spine variable, most resembling that of femur-rubrum. Scoop of ovipositor in side view without angulation at junction with stem (Fig. 4Ia). . . . . . M. extremus.

\title{
ON SOME NEW AND ANOMALOUS TETTIGONINAE.
}

BY C. F. BAKER, AUBURN, ALA.

The following new species belong to genera not before recorded from America. 'They occupy as anomalous a position among the Tettigoninae, as does Tinobregmus among the Jassinae. Like 'Tinobregmus, they present a remarkable difference in the two sexes, and are heavily robust in form. All four species belong to the far west, the eastern limit being Colorado.

The ocelli are not as near the front margin of the vertex as in some other unquestioned Tettigonids. Compared with Acocephalus, the eyes are distant from the front edge of vertex, and occupy a position never approached by the ocelli in Acocephalus. Besides, other details of structure show a closer relationship with the Tettigonine series where I have placed them. The single species of Bathysmatophorus, reutri, was described from the Scandinavian countries. Errhomenus, with its single species, brachypterus, is quite widely distributed in Central Europe.

Bathysmatophorus uhleri $\mathrm{n}$. sp. Length of $q 9.5 \mathrm{~mm}$. Color pale brownish, irrorate with darker, minutely so on head and pronotum, coarsely on dorsum and fore femora.

Vertex about a half longer on middle than next eyes, rather strongly depressed; ocelli about midway of its length, and somewhat nearer the median line than to eyes. The front subrectangular in general outline, a little broader above, somewhat timidly extended, and crossed by numerous faint dark arcs. Clypeus regularly oblong, nearly two- 
thirds the length of the front and distinctly exceeding the genae. Genae very strongly incurved below the eyes, making the latter unusually protuberant. Pronotum little longer than vertex, faintly transversely aciculate and with several shallow transverse creases or constrictions. Elytra trapezoidal in outline, reaching the middle of last dorsal segment ; color sordid whitish with numerous fine irregular irrorations, which are more distinct on veins. Fore and middle femora with numerous small white spines. All tibiae more or less marked with dark.

Last ventral segment a half longer than preceding and with it having a slight median keel; hind margin truncate with a median notch reaching half the length of the segment. Ovipositor nearly one-third the length of the body and exceeding the pygofers by nearly I $\mathrm{mm}$.

Length of $\delta$ to $8 \mathrm{~mm}$. Much darker than the female, the sternum and most of venter black. In some specimens the upper part of face is shining black. The vertex is shorter and the pronotum less strongly arcuated behind. The elytra exceed the abdomen by .5 to $.75 \mathrm{~mm}$. The plates are long, slender, acutely curved upwards distally, and supplied at base with a slight transverse callosity. The valve is short and very obtusely angulate. The last ventral segment is broadly roundly extended backwards at middle.

Described from one female and several males in the National Museum, collected at Los Angeles, Cal., by Mr. Coquillett and at Dunsmuir, Cal, by Mr. Wickham. These specimens bore the Mss. name Lystridea conspersa Uhl. Ulheri seems to be entirely congeneric with reuteri.

Errhomenus lineatus n. sp. Length of $q$ $7 \mathrm{~mm}$. Color pale yellowish brown. Head slightly wider than pronotum. Vertex bluntly angulate, nearly twice longer at middle than at eyes, once and a half the length of pronotum; numerous indistinct brownish transverse arcs on front; two black dots near hind margin of disc of vertex. Ocelli at about half length of vertex and equidistant from median line and anterior margin of vertex. Clypeus broad at base, rapidly narrowing to the oval tip which pro. jects beyond the genae. Pronotum short, the width twice and three fourths the length, fore and hind margin nearly parallel, the latter broadly angularly emarginate; laterally distinctly carinate; disc with a transverse row of about six black dots; anterior margin with a conspicuous though not large black spot behind each eye. Elytra obliquely truncate behind, not equalling second abdominal segment, sordid whitish in color, the discs of cells darker. Dorsum with a double median longitudinal row of black dots, each segment with about two transverse rows of minute black points; the spiracles in black dots. Sternum more or less black laterally.

Last ventral segment twice length of preceding, the hind margin truncate, with a very shallow median notch. Ovipositor slightly exceeding pygofers.

Length of $35.5-6 \mathrm{~mm}$. Far darke and more heavily marked than the female. Vertex shorter than pronotum and more strongly irregularly concave. A more or less well-defined dark median line extending from point of vertex to scutel. All below except legs largely black, sparingly irregularly irrorate with yellowish; a conspicuous. yellowish band extending from beneath antennal pit back upon the proplurae. Femora lineate with dark. Dorsum black with a few whitish points. Elytra exceeding abdomen by about one $\mathrm{mm}$., sordid white with irregular dark cloudings in the cells. Wings transparent, slightly smoky apically.

Valve black, scarcely exserted, remainder of genitals more or less sordid whitish. 
Plates long, slender, parallel sided below, becoming acute apically and curving upward.

Described from two females and five males taken at Pullman, Wash., by Prof. C. V. Piper.

Errhomenus montanus n. sp. Length of o 6.5-7 mm., of $\delta 5.25-6 \mathrm{~mm}$. Very close to lineatus. The last ventral segment of female is distinctly produced medially within the protruding lateral angles; the apex with a small median notch. The plates of the male are not as acute or strongly bent upwards as in lineatus. The elytra of the male exceed the abdomen but little, and lack any noticeable contrast of colors.

Described from three females and four males collected by myself in northern Colorado. They occurred in the foot-hills west of Fort Collins in May, and at Cameron Pass from 10000 feet to above timber, during July. I was at first inclined to place this with lineatus as a variety, but would at present be scarcely justified in so doing. Series from points between Washington and the mountains of Colorado are needed to decide the question.

Errhomenus oregonensis n. sp. Length of $\$ 7 \mathrm{~mm}$. Closely resembling a fully colored example of montanus. The vertex is proportionally shorter and more blunt. The front is more tumid and as viewed from the side not evenly curved upon the clypeus. The anterior legs are unusually pale. The head is about as broad as pronotum. The elytra are broadly rounded behind instead of being obliquely truncate, and they slightly exceed the second segment.

Length $\delta, 5-5.5 \mathrm{~mm}$. The male has abbreviated elytra which reach only the penultimate dorsal segment. The colors, sordid white to black, are more sharply contrasted than in the other species, though similarly disposed. The transverse row of black spots on the pronotum is very sharply defined, though the darker longitudinal band is wanting. The abbreviated elytra flare slightly, giving the male a shortened, robust appearance which is very suggestive of Tinobregmus.

Described from one female taken at Corvallis, Oregon, by Prof. A. B. Cordley, and several specimens in the National Museum collected in Oregon by $\mathrm{Mr}$. Koebele. The shortened elytra of the male brings a new element into the genus, but the relationships of the female with lineatus and montanus are unquestionable.

\section{THE COCCID GFNUS SOLENOPHORA IN THE UNITED STATES.}

BY T. D. A. COCKERELL, N. M. AGR. EXP. STA.

The genus Solenophora Maskell, is represented by two species confined to New Zealand, so far as published information goes. Mr. Maskell has been kind enough to send me specimens of both these species; to them I have just added a third, collected by $\mathrm{Mr}$. Koebele in Mexico, and transmitted to me by Dr. Howard. To thus receive a supposed endemic New Zealand genus from Mexico was indeed surprising; but to-day, before the report on the Mexican material has appeared in print, there comes to hand yet another species, from Colorado!

Solenophora coloradensis, n. sp. $\$$. Scale 

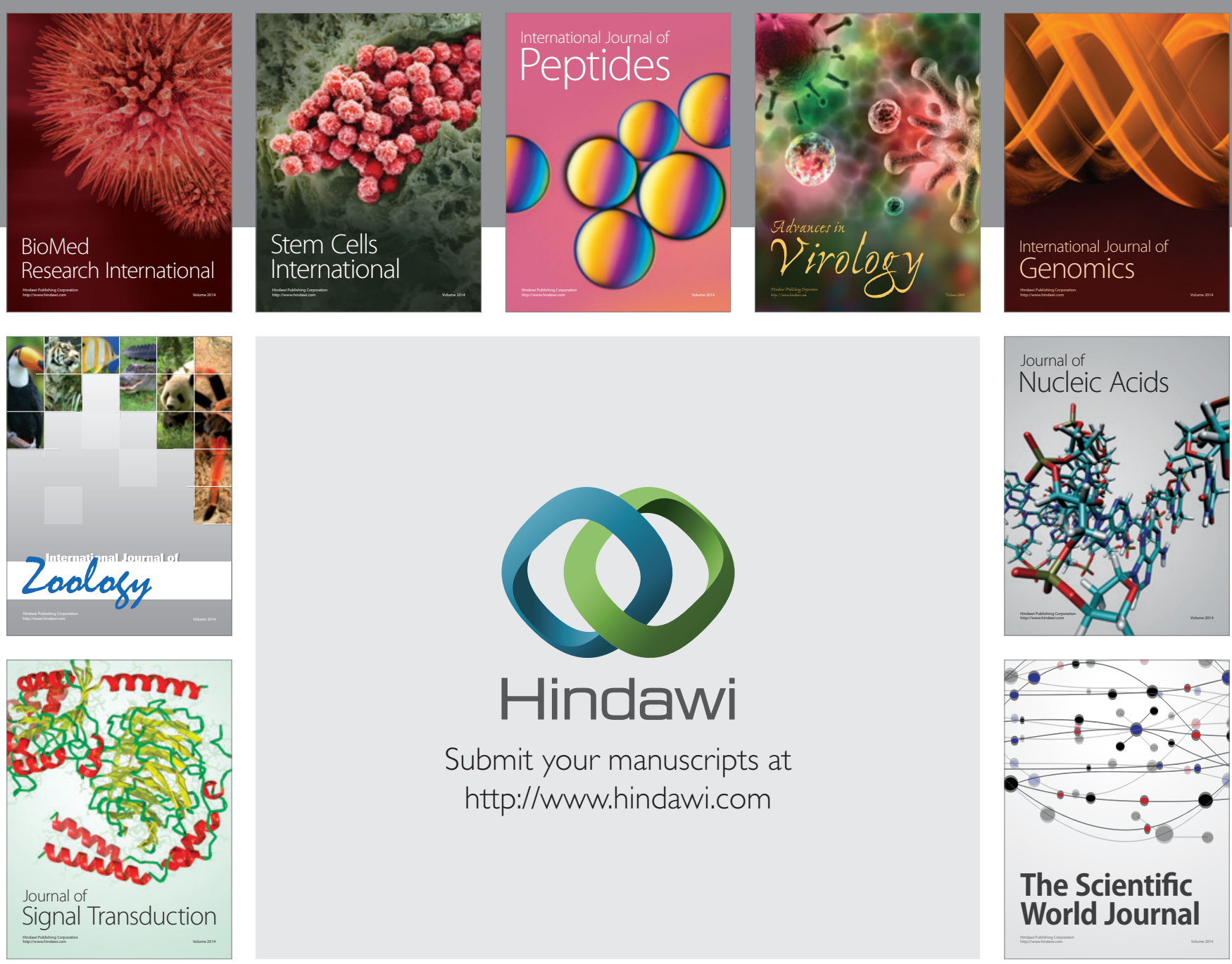

Submit your manuscripts at

http://www.hindawi.com
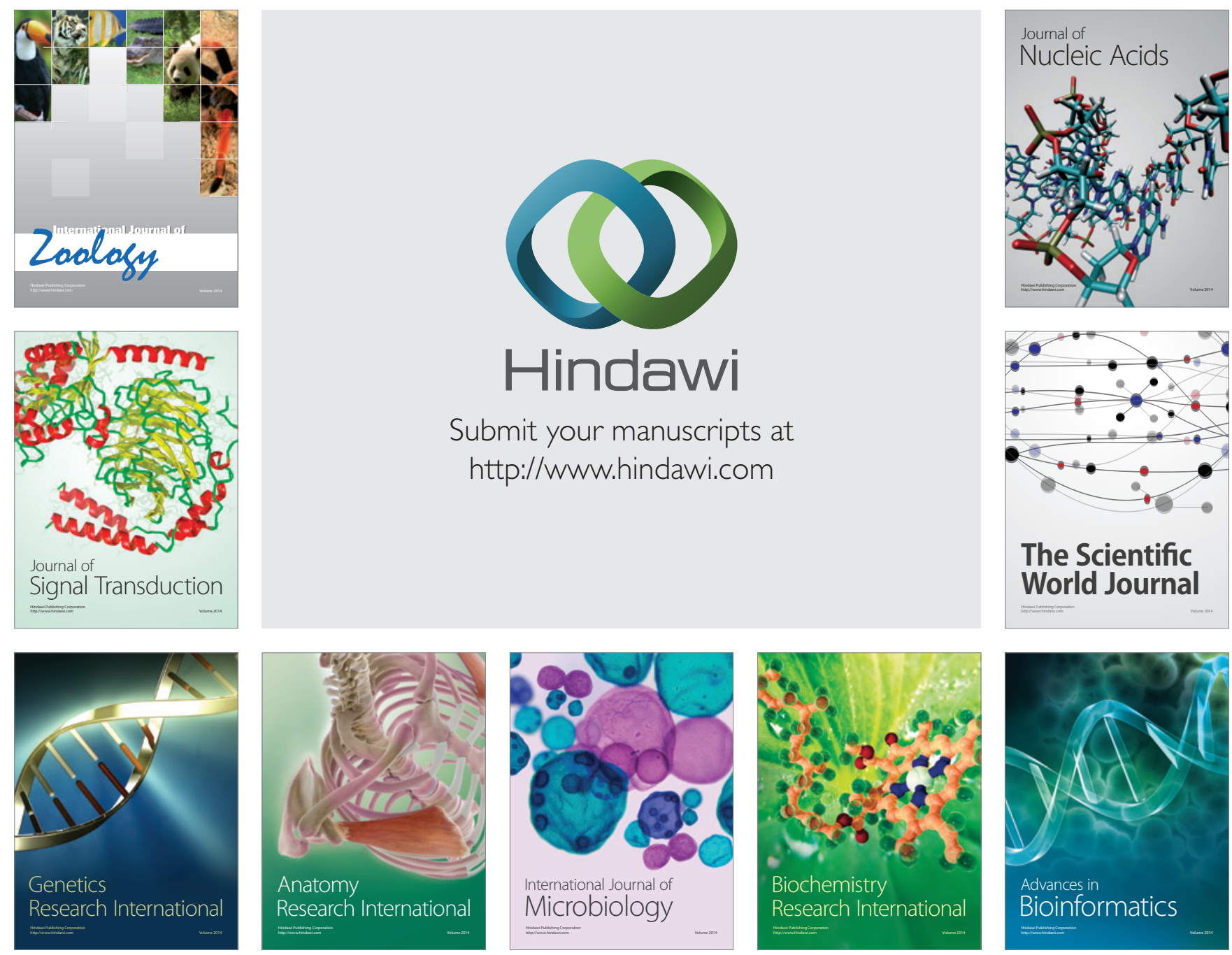

The Scientific World Journal
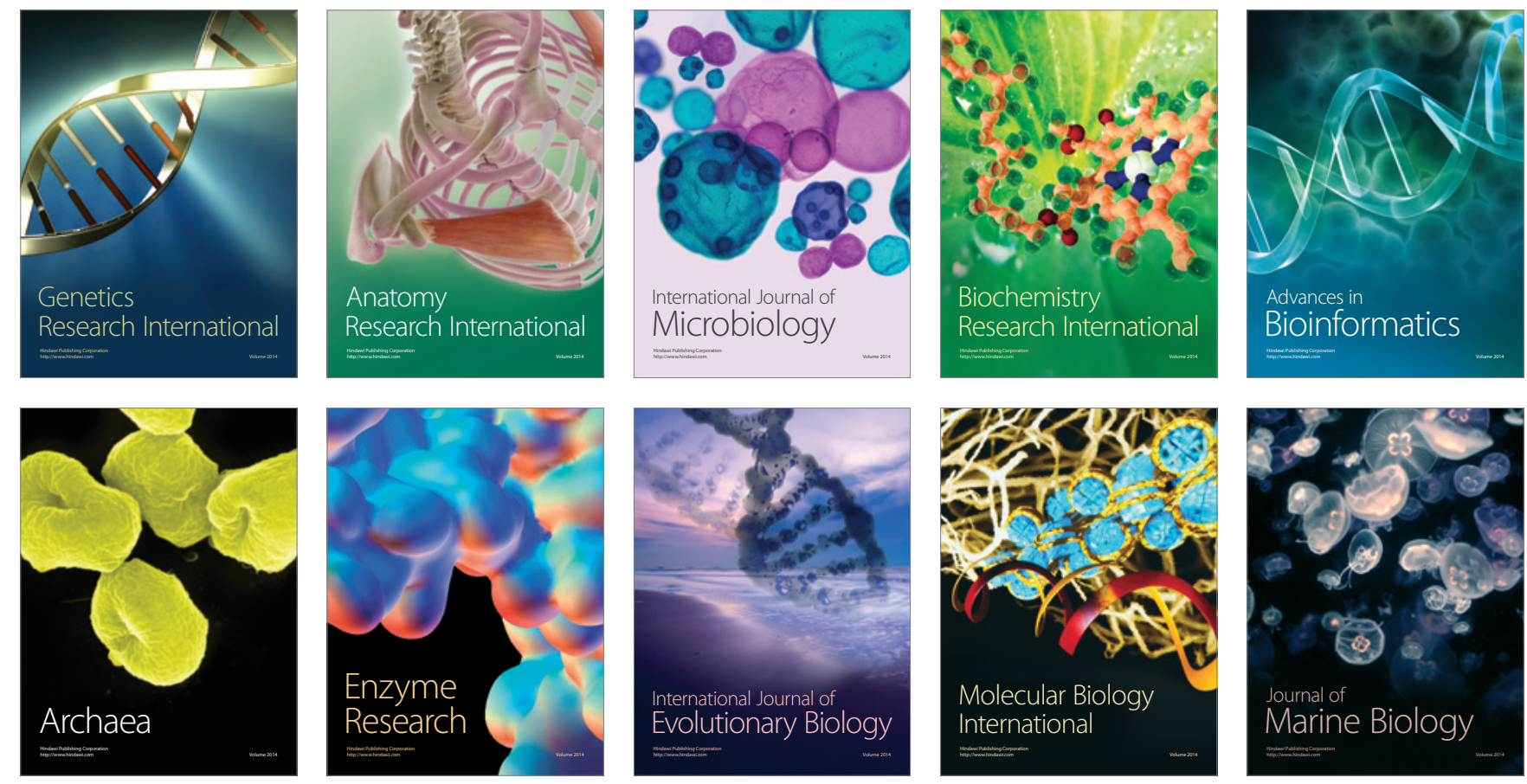